\title{
Waste management in non-hospital emergency units ${ }^{1}$
}

\author{
Milca Severino Pereira ${ }^{2}$ \\ Sergiane Bisinoto Alves ${ }^{3}$ \\ Adenicia Custódia Silva e Souza ${ }^{4}$ \\ Anaclara Ferreira Veiga Tipple ${ }^{5}$ \\ Fabiana Ribeiro de Rezende ${ }^{6}$ \\ Érika Goulart Rodrigues ${ }^{7}$
}

Objective: to analyze waste management in urgency and emergency non-hospital health care service units. Method: Epidemiological cross-sectional study undertaken at three NonHospital Emergency Units. The data were collected using systematic observation, registered daily in a spreadsheet and checklist, and analyzed through descriptive statistics. Results: the generation of waste varied from 0.087 to $0.138 \mathrm{~kg}$ per patient per day. Waste management showed inadequacies in all stages, especially in the separation stage. Infectious waste was found together with common waste, preventing recycling, and piercing and cutting objects were mixed with waste from different groups, increasing the risk of occupational accidents. Conclusion: the study reveals the lack of an institutional waste management policy, as demonstrated by the failure of operational stages, involving problems related to management, physical structure, material and human resources at the units. This is relevant for health care units, considering the quality of patient care and its interface with sustainability.

Descriptors: Medical Waste; Waste Management; Nursing.

\footnotetext{
${ }^{1}$ This research was supported by Conselho Nacional de Desenvolvimento Científico e Tecnológico (CNPq), process \# 568893/2008-5.

2 PhD, Adjunct Professor, Pontifícia Universidade Católica de Goiás, Brazil.

3 Doctoral Student, Faculdade de Enfermagem, Universidade Federal de Goiás, Brazil.

${ }^{4}$ PhD, Adjunct Professor, Pontifica Universidade Católica de Goiás, Brazil. Volunteer Professor, Faculdade de Enfermagem, Universidade Federal de Goiás, Brasil.

${ }^{5} \mathrm{PhD}$, Associate Professor, Faculdade de Enfermagem, Universidade Federal de Goiás, Brasil

${ }^{6}$ Undergraduate student, Faculdade de Enfermagem, Universidade Federal de Goiás, Brazil.

7 Master's student, Faculdade de Enfermagem, Universidade Federal de Goiás, Brazil.
}

Corresponding Author:

Milca Severino Pereira

Rua 1028, 70, Apto 1801

Residencial Akkar, Setor Pedro Ludovico

CEP: 74823-130, Goiânia, GO, Brasil

E-mail: milcaseverino@gmail.com 


\title{
Gerenciamento de resíduos em unidades não hospitalares de urgência e emergência
}

Objetivo: analisar o gerenciamento de resíduos nos serviços de saúde, em unidades não hospitalares de atendimento às urgências e emergências. Método: estudo epidemiológico, transversal, realizado em três unidades não hospitalares de atendimento às urgências e emergências. Os dados foram coletados por meio de observação sistematizada e registrados diariamente em planilha e checklist e analisados por meio de estatística descritiva. Resultados: a geração de resíduos variou de 0,087 a 0,138kg/usuário/dia. O manejo de resíduos apontou inadequações em todas as etapas, principalmente na segregação. Encontraram-se resíduos infectantes adicionados aos comuns, inviabilizando a reciclagem, bem como perfurocortantes misturados aos diferentes grupos, aumentando o risco de acidente ocupacional. Conclusão: o estudo revela a inexistência de política institucional de gerenciamento de resíduos, evidenciada por falhas nas etapas operacionais que envolvem problemas de gestão, estrutura física, recursos materiais e humanos das unidades. Apresenta relevância para os estabelecimentos de saúde no que tange à qualidade do atendimento ao usuário e à sua interface com a sustentabilidade.

Descritores: Resíduos de Serviços de Saúde; Gerenciamento de Resíduos; Enfermagem.

\section{Manejo de residuos en las unidades no hospitalarias de urgencia y emergencia}

\begin{abstract}
Objetivo: analizar la gestión de los residuos en unidades hospitalarias de emergencias y urgencias. Método: estudio epidemiológico. Los datos fueron recolectados por observación sistemática, registrados diariamente en una hoja de cálculo y check list y analizados mediante estadística descriptiva. Resultados: la generación de residuos varió desde 0,087 hasta $0,138 \mathrm{~kg} /$ usuario / día. La gestión de los residuos mostró deficiencias en todas las etapas, especialmente en la segregación. Fueron encontrados residuos infecciosos añadidos a los comunes, invalidando el reciclaje, así como materiales punzantes y cortantes mezclados con los diferentes grupos, amentando el riesgo de accidentes de trabajo. Conclusión: el estudio revela la ausencia de una política institucional para la gestión de los residuos, como lo demuestran las fallas en las medidas operacionales, que implican problemas de gestión, estructura física, recursos materiales y humanos de las unidades. Muestra relevancia para los servicios de salud en lo que se refiere a la calidad del servicio para el usuario y su interfaz con la sostenibilidad.
\end{abstract}

Descriptores: Residuos de Servicios de Salud; Gestión de Residuos; Enfermería.

\section{Introduction}

Concern with the waste produced in various human activities is recent, in particular those resulting from health care. Resolutions number 306 of the National Environment Agency - ANVISA, from $2004^{(1)}$ and 358 of the National Environment Board - CONAMA, from 2005(2), represented a landmark, as they established harmonization between the regulators concerning Health Care Service Waste (HCSW) and changed the management responsibility to the waste generators.

The publication of Federal Rule 12.305 on August $2^{\text {nd }} 2010^{(3)}$, which introduced the national solid waste policy, is another progress in the search for appropriate procedures. It obliged states and local councils to develop their management plans, which will optimize waste management in two spheres and can cause eco- environmental, socio-economic and occupational impacts. Health care service waste is the waste resulting from all human or animal health care activities, including home care and field work. It is classified into five groups: A - infectious, B - chemical, C - radioactive, $\mathrm{D}$ - common and $\mathrm{E}-$ piercing and cutting ${ }^{(1-2)}$.

The Resolutions cover all management stages, from separation until final disposal, aiming to protect professionals and the environment ${ }^{(4-5)}$. Nevertheless, at non-hospital emergency units, there is still little concern with these issues, despite their responsibility to manage their waste.

International authorities are concerned with the issue of the different waste types produced by the community, and not only with health care service waste $^{(6)}$. Another challenge relates to the environment, 
in particular to the regulation and final destination rules in different countries ${ }^{(7)}$.

This issue represents a critical problem because it poses a direct threat to human health, as well as to the environment ${ }^{(8)}$. One fourth of the waste produced by health care services is considered dangerous, with potential risks for the health care workers and the community ${ }^{(9)}$.

Considering the impact of HCSW upon the ecosystem and its epidemiological meaning in the public health care context, we question: How is this issue dealt with at this service? Is there a systematic institutional policy for its management?

The issue concerning HCSW is of upmost relevance for the safety of health care professionals and for the preservation and conservation of the environment, as well as for the construction of new health care paradigms.

In that sense, the objective of this study was to analyze the management of the waste produced at nonhospital emergency units.

\section{Method}

This epidemiological and cross-sectional study was undertaken at three Non-Hospital Emergency Units, called Integral Health Care Centers, in an administrative region in the city of Goiania, Brazil. These units are able to provide effective care to patients with acute or chronicacute problems. They receive uninterrupted support from the clinical pathology laboratory for urgencies, radiology, equipment for emergency care, medication dispensation and observation beds for periods from 6 to 24 hours.

The data were collected between March and April 2010 by means of systematic observation of waste management and quantification. The place and time for its weighing at each unit were arranged with the managers and the data collection was done over a period of seven consecutive days, in the mornings and afternoons, during four hours each shift, considering all shifts, day and night. This stage involved support from ten research assistants from the Nursing Research Centre for Prevention and Control of HealthcareAssociated Infection - NEPIH/UFG.

As regards quantification, electronic scales were used for quantification, with maximum capacity of $30 \mathrm{~kg}$ and minimum of $5 \mathrm{~g}$, which was registered at the National Metrology, Normalization and Industrial Quality
Institute (INMETRO). Before each weighing, the level of flatness of the scale was verified against the carpentry level, according to the manufacturer's instruction.

The bags were collected from the temporary storage and taken to the weighing place, which had been previously prepared with the scales and the recipients for the different types of waste. Each bag was weighted twice, firstly in the form it had been disposed for public collection, taking into consideration the color of the bag to classify the contents as infectious or not. After that, the bags were opened and the waste was separated according to Brazilian legislation(1), followed by a new weighing.

Each day, notes were registered in a spreadsheet and checklist, considering the weight and the separation per group. A field diary was used to register the information related to the dynamics of the management flow.

To protect the researchers, a standardized occupational safety protocol was adopted and discussed in detail with the research assistants. All of them went into the field duly vested, according to the Labor Ministry's(10) recommendations. Cherron tweezers were used in the separation process.

Chemical and radioactive waste was not included in this study: the radioactive waste because it was not produced at the units where this study was undertaken, and the chemical waste due to quantification difficulties, resulting from the different ways of disposal, some in the sewage system and others stored under water seal and/or forwarded to the centralized units in the original bags.

The information was processed through SPSS - Statistical Package for the Social Sciences software and grouped in tables, using descriptive statistics, calculating the average daily production per unit and per patient/day.

The project received approval from the Ethics Committee of Hospital das Clinicas at Universidade Federal de Goias, under registration number 029/09. The study was authorized by the Local Council Health Bureau of Goiania, in the state of Goias.

\section{Results}

Units I, II and III produced an average $90.0 \mathrm{~kg}$, $78.0 \mathrm{~kg}$ and $40.1 \mathrm{~kg}$ of waste per day, respectively. Table 1 shows the daily production per group in each unit. 
Table 1 - Daily weight* in kg, and percentage of waste produced at three Non-Hospital Emergency Units, distributed according to group. Goiania, GO, Brazil, 2010.

\begin{tabular}{|c|c|c|c|c|c|c|c|c|}
\hline \multirow{2}{*}{ Units } & \multicolumn{2}{|c|}{ Group A } & \multicolumn{2}{|c|}{ Group D } & \multicolumn{2}{|c|}{ Group E } & \multicolumn{2}{|c|}{ Total } \\
\hline & Weight & $\%$ & Weight & $\%$ & Weight & $\%$ & Weight & $\%$ \\
\hline Unit I & 10.588 & 11.7 & 73.318 & 81.4 & 6.135 & 6.9 & 90.041 & 100 \\
\hline Unit II & 10.890 & 13.5 & 62.519 & 80.5 & 4.634 & 6.0 & 78.043 & 100 \\
\hline Unit III & 0.789 & 9.8 & 32.037 & 81.8 & 3.279 & 8.4 & 40.105 & 100 \\
\hline Total & 22.267 & 10.7 & 167.874 & 80.6 & 14.048 & 6.8 & 208.189 & 100 \\
\hline
\end{tabular}

*This weight was obtained after the separation process undertaken by the researchers and represents the real waste weight in each group.

The sectors that most produced waste from group A were the treatment room, followed by dentistry services and nursing room. Amongst them, the following predominated: bandage covers, catheters, bandages and dressings containing large quantities of blood, gynecologic brushes, speculum, Ayres spatulas, dentistry suckers and teeth, and others. Waste from group A was found in places where it is not produced, like the coffee room and external areas.

The most produced types of waste at the units belonged to group $\mathrm{D}$ and are as follows: packaging, intravenous drip bags, cardboard boxes, cups, paper towels and leftover food.

Table 2 shows waste management inconsistencies, particularly related to the separation process. More than $80 \%$ of group D waste could be recycled. At all units, however, waste from group $A$ and $E$ was found packed together with that from group $D$. Only in one unit were cardboard boxes and plastic bottles separated for recycling.

During the data collection process, the researchers witnessed an accident in one of the units, where a cleaning worker was perforated in the leg by a hollow needle during common waste collection, which should only have contained group $\mathrm{D}$ waste.

The three units packed $0.654 \mathrm{~kg}$ of piercing and cutting waste per day, in creamy white plastic bags, together with waste from group $A$. These included needles, scalpel blades and glass flasks.

Table 2 - Daily weight of waste from groups A and D, according to the separation process undertaken by the health care professionals and researchers (real weight), at three Non-Hospital Emergency Units. Goiania, GO, Brazil, 2010.

\begin{tabular}{|c|c|c|c|c|c|c|}
\hline \multirow{2}{*}{ Separation by group } & \multicolumn{2}{|c|}{ Unit I } & \multicolumn{2}{|c|}{ Unit II } & \multicolumn{2}{|c|}{ Unit III } \\
\hline & Weight & $\%$ & Weight & $\%$ & Weight & $\%$ \\
\hline Separated as group A & 24.963 & 100 & 30.754 & 100 & 18.443 & 100 \\
\hline Only Group A & 8.174 & 32.7 & 9.242 & 30.1 & 4.404 & 23.9 \\
\hline Group D* in Group A* & 16.749 & 67.1 & 21.349 & 69.4 & 13.588 & 73.7 \\
\hline Group E* in GroupA & 0.04 & 0.20 & 0.163 & 0.5 & 0.451 & 2.4 \\
\hline Separated as group D & 59.035 & 100 & 42.851 & 100 & 18.902 & 100 \\
\hline Only group D & 56.569 & 95.8 & 41.17 & 96.1 & 18.449 & 97.6 \\
\hline Group A in Group D & 2.414 & 4.10 & 1.648 & 3.80 & 0.385 & 2.0 \\
\hline Group E in Group D & 0.052 & 0.10 & 0.033 & 0.1 & 0.680 & 0.4 \\
\hline
\end{tabular}

Table 3 - Daily waste produced at the three Non-Hospital Emergency Units per patient/day, according to the group. Goiania, GO, Brazil, 2010.

\begin{tabular}{|c|c|c|c|c|c|c|c|c|}
\hline \multirow{2}{*}{ Unit - separation } & \multicolumn{2}{|c|}{ Group A } & \multicolumn{2}{|c|}{ Group D } & \multicolumn{2}{|c|}{ Group E } & \multicolumn{2}{|c|}{ Total } \\
\hline & kg/pt/day & $\%$ & $\mathrm{~kg} / \mathrm{pt} / \mathrm{day}$ & $\%$ & kg/pt/day & $\%$ & kg/pt/day & $\%$ \\
\hline Unit I & 0.01 & 9.4 & 0.09 & 84.1 & 0.007 & 6.5 & 0.107 & 100 \\
\hline Unit II & 0.02 & 14.5 & 0.11 & 79.7 & 0.008 & 5.8 & 0.138 & 100 \\
\hline Unit III & 0.01 & 11.5 & 0.07 & 80.4 & 0.007 & 8.1 & 0.087 & 100 \\
\hline
\end{tabular}

$\mathrm{Pt}=$ patient

The majority of the units $(66.7 \%)$ used identified bags for infectious waste, but only $33.3 \%$ identified the packaging containers.
Collection and internal transportation were $100 \%$ undertaken at pre-established times and, on all occasions, group A and group D waste were collected at 
the same time. All units emptied and re-used the bags that stored waste belonging to group D. None of the units had a specific place for temporary storage.

Two units had an exclusive place for external storage. At both, there was a specific place for waste from groups $A$ and $E$ and another place for waste from group D. Only one storage place was identified and, in addition, $100 \%$ did not have restricted staff access and was kept open.

One storage place was brickwork with washable floors and regular decontamination. The bags, however, were placed directly on the floor. Concerning the other storage place, the building did not comply with the legal parameters set and had only one structure of bars and roof; the waste was disposed into containers and there was no regular decontamination process. At another unit, the waste was disposed in containers, one container for groups $A$ and $E$ and another for group $D$ waste, and none of them had a lid. These containers were in places of easy access to collector vehicles, but also to the population.

None of the units undertook any previous treatment for waste when this was required. The external collection took place three times a week and the collection of groups $D$ and A/E waste was done separately.

\section{Discussion}

No study was found about waste management at non-hospital emergency units; several publications about waste management in hospitals were found though(11-12).

The three units produce $208.189 \mathrm{~kg}$ of waste per day. Although the results of this study could not be compared with findings from other ones, due to the fact that they do not use the same measuring unit and present different care forms, an investigation undertaken at primary health care units showed that 270 liters of waste were produced per day on average, and that none of them had a management plan(13).

According to Brazilian legislation ${ }^{(1)}$, waste separation at the source and while it is being produced is compulsory, in accordance with its type, aiming to reduce the volume to be treated and disposed at the final destination and ensuring protection to health and environment.

The data revealed that only part of the waste produced at the three non-hospital units is potentially infectious, that is, $22.267 \mathrm{~kg}$ per day, which represent $10.7 \%$ of infectious waste. Despite this fact, if the waste separation is not adequately done during its production, all of the waste that is mixed with that of group A should be treated as potentially infectious and requires special procedures for its storage, collection, transportation and final disposal, thus increasing the treatment costs ${ }^{(14-15)}$. The separation process was shown to be essential for all HCSW management and directly affected the next stages, recycling, occupational safety and the environment.

Concerning the hospitals, the separation process is also inappropriate and there is an urgent need to implement a management plan and provide training to the professionals involved(15).

In this study, the health care units did not undertake adequate waste separation. Piercing and cutting waste (group E) and common waste (group D) were found separated as infectious (group A) in creamy white plastic bags. This means that, in one week, $361.802 \mathrm{~kg}$ of common waste was unnecessarily contaminated at the three units and this was forwarded for treatment, which increased the costs and also the damage to the environment.

A study found that $98.8 \%$ of health care professionals were aware of the importance of waste management resulting from their patient care, but $76.4 \%$ did not know the color codes used in waste

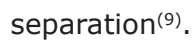

In dentistry services, $75 \%$ of the dental surgeons interviewed were aware of waste management, but only $67 \%$ of them followed the rules in the execution of their work and their main concern was mercury management ${ }^{(8)}$.

In the present study, $3.8 \%$ of infectious waste (A) and $0.6 \%$ of piercing and cutting waste (E) were separated per day as common waste (D) and contaminated the common waste, which was not treated when forwarded for public collection, therefore causing damage to the environment and risks to waste collectors and workers.

As regards health care clinics, $21.5 \%$ of them did not undertake separation and $26.34 \%$ did not have specific plastic bags for storage ${ }^{(12)}$.

Also, group A waste was present in places where it was not produced, like coffee rooms and administrative areas, which shows that this waste was probably not disposed correctly after its production, therefore breaching applicable recommendations ${ }^{(1-2)}$.

The results found, especially regarding the presence of piercing and cutting objects in plastic bags without any protection, revealed that the professionals working at the units under analysis did not incorporate 
appropriate waste separation into their practice. The breaching of this important stage of waste management exposes those people who separate the waste, the health care team, patients and their visitors, public collection workers, waste collectors and the environment to safety risks.

The main causes of accidents with piercing and cutting objects containing biological material are associated to their disposal in inappropriate places ${ }^{(6,16-17)}$, being the proper management of HCSW a biosafety issue ${ }^{(14,18)}$. Primary health care professionals, however, consider that the risk of HIV infection in their daily practice is low ${ }^{(19)}$.

This situation can be evidenced by the accident with a sharp object involving a cleaning worker who was exposed to biological material while collecting common waste from the coffee room during the study period. On that occasion, the worker was duly vested and the accident happened due to inappropriate waste separation.

Risk factors for seroconversion by HIV(20-21) are more related to the type of accident, the objects involved and their place of use, serology of the source patient, than to the workplace of the person suffering the accident.

In one week, the three units could have forwarded $639.329 \mathrm{~kg}$ of common waste for recycling. This action would have reduced the damage caused to the environment and preserved it, due to the decrease in the extraction of raw materials, and would also generate income.

Health education activities significantly further knowledge about solid waste management, using the best practices in terms of management and recycling. Principles like eco-efficiency should be addressed amongst health care professionals.

The waste production per patient/per day at the research units varied between 0.087 and $0.138 \mathrm{~kg}$ per patient a day. Studies analyzing the production of waste per patient a day at emergency units were not found for comparison with our information.

In relation to other management stages, the identification of the waste is as important in relation to the bags as it is in relation to the storage containers. This identification should be attached to an easily visible place, listing the type of waste that should be disposed in each. Non-compliance with this stage compromises waste management.

Only the containers for disposal of piercing and cutting objects were identified at all units. This is not just because it is compulsory, but also due to the fact that the disposal containers are standardized by the Brazilian Technical Rules Association (ABNT).

Internal transportation in the units was done through trolleys, according to the Resolution's recommendations ${ }^{(1)}$. Nevertheless, all waste from group $D$ was collected together with that from groups $A$ and $E$, disregarding the legislation ${ }^{(1)}$.

At only one unit, the external storage place was built according to the rules ${ }^{(1)}$, but the waste was directly disposed on the ground and the place was not kept locked. At the other units, the waste was disposed in areas of easy access for external collection and for the population.

Inappropriate external storage exposes the entire population to risks, mainly those people who try to survive by looking in rubbish bins. At one unit, people looking into storage containers for common waste are frequent, aiming to find something for recycling or as a source of income. In addition, the waste disposed in inappropriate places instigates the appearance of rodents, vectors and other animals.

Inappropriate waste management at the units studied was caused by failures in management and infra-structure, as illustrated by the use of non-identified creamy white bags and containers, the lack of internal storage and inappropriate external storage.

As observed, the lack of waste management is many times due to professionals' lack of knowledge about this issue, which affects health care workers as well as the cleaning and hygiene workers. On some occasions, the creamy white bag contained only bathroom waste. The same bag was also used in bins located in the corridor, meaning that it is also used in inappropriate places. These facts show negligence on the part of the units' professionals and management.

Problems related to incorrect management are complex and require not only conscientious positioning, but, above all, availability to cooperate in their resolution (23). This availability should involve management, workers, educational institutions, regulators and political will of states and local councils.

Concerns with group $B$ waste are still emerging. The professionals are not aware of the place where mercury and its derived substances end up. Disinfectants and developers are disposed in the environment without any previous treatment. Other studies should be undertaken to regulate their management at non-hospital units.

The inability to quantify chemical waste (group B) disposed in sewage system, as well as medication rests left in the flasks, represents a study limitation. 


\section{Conclusion}

The units produced a total of $208.189 \mathrm{~kg}$ of waste per day and, of the $80.6 \%$ of common waste produced, $67.1 \%$ of it was disposed with infectious waste, which made recycling unfeasible. Waste production per patient/day varied from $0.087 \%$ to $0.138 \%$.

The analysis of the waste management produced in non-hospital emergency units in the city of Goiania - GO indicated failures related to all operational stages, physical structure, management and material resources and reveals the lack of an institutional policy. Separation, considered the most important stage of waste management, presented most errors, therefore compromising the next stages and increasing costs and risks.

Knowledge about this reality represents the initial stage for the development of a management plan. This permits the planning and re-adaptation of the physical structure and material and human resources, as well as the identification of the critical points to addressed in terms of continuing education. The development of a waste management plan for health care services (WMPHCS), as proposed by the legislation, together with continuing education for professionals, is an advance in solving the identified problems.

This study can instigate further interest in relation to the extent of the problem and stimulate the implementation of systematic control measures to minimize the threats to health and the environment.

Professional Nursing, as a large producer and separator of waste, has a major role in the development of a management plan. This should be discussed in a broad and interdisciplinary manner, and also reflect ethical, ecological and compromised positioning on the part of the professionals, including social ethics and ecoenvironmental responsibility.

The most important point in this research is related to its meaning to health care providers, concerning the quality of patient care and its interface with sustainability. Based on the information obtained and on the literature, clear negligence exists in the procedures related to concerns with environmental impact and its consequences for society. Nursing professionals can and need to contribute to this cause.

\section{References}

1. Ministério da Saúde (BR). Agência Nacional de Vigilância Sanitária. Resolução RDC n 306, de 07 de dezembro de 2004. Dispõe sobre o Regulamento técnico para o gerenciamento de serviços de saúde. Brasília (BR): Ministério da Saúde; 2004.

2. Ministério do Meio Ambiente (BR). Conselho Nacional do Meio Ambiente. Resolução 358 de 29 de abril de 2005. Dispõe sobre o tratamento e a disposição final dos resíduos dos serviços de saúde e dá outras providências. Brasília (BR): Ministério do Meio Ambiente; 2005.

3. Presidência da Republica (BR). Lei Federal No. 12305, de 02 de agosto de 2010. Institui a Politica Nacional de Resíduos Sólidos, altera a lei no. 9605, de 12 de fevereiro de 2008 e dá outras providencias. Brasília (Brasil): Casa Civil; 2010.

4. Ministério da Saúde (BR). Agência Nacional de Vigilância Sanitária. Manual de gerenciamento de resíduos de serviços de saúde. Brasília (BR): Ministério da Saúde; 2006.

5. Naime R, Ramalho AHP, Naime IS. Avaliação do Sistema de gestão dos resíduos sólidos do Hospital das Clínicas de Porto Alegre. Rev Espaço para a Saúde. 2007;9(1):1-17.

6. Gold K. Analysis: The impact of needle, syringe, and lancet disposal on the community. J Diabetes Sci Tecnol. 2011;5(4):848-50.

7. Canadian Medical Association. Medical wastemanagement practices vary across Canada. CMAJ. 2011;183(18):E1307-8. doi:10.1503/cmaj.109-4032.

8. Sood AG, Sood A. Dental perspective on biomedical waste and mercury management: a knowledge, attitude, and practice survey. Indian J Dent Res. 2011;22:371-5. 9. Basu M, Das P, Pal R. Assessment of future physicians on biomedical waste management in a tertiary care hospital of West Bengal. J Nat Sci Biol Med. 2012;3(1):3840. doi: 10.4103/0976-9668.95945.

10. Ministério do Trabalho (BR). Portaria n 485, de 11 de novembro de 2005 - Aprova a norma regulamentadora no 32 - Segurança e Saúde no Trabalho em Serviços de Saúde. Brasília (Brasil): Ministério do Trabalho; 2005.

11. Soysal A, Simsek H, Soysal D, Alyu F. Management of health-care waste in Izmir, Turkey. Ann Ist Super Sanità. 2010;46(3):299-302.

12. Ramos YS, Pessoa YSRQ, Ramos YS, Araújo Netto FB, Pessoa CEQ. Vulnerabilidade no manejo dos resíduos de serviços de saúde de João Pessoas (PB, Brasil). Ciênc Saúde Coletiva. 2011;16(8):3553-60.doi:10.1590/ S1413-81232011000900023.

13. Nazar MW, Pordeus IA, Werneck MAF. Gerenciamento de resíduos sólidos de odontologia em postos de saúde da rede municipal de Belo Horizonte. Rev Panam Salud. Publica. 2005;17(4):237-42.

14. Alves SB, Souza ACS, Tipple AFV, Rezende KCD, 
Rezende FR, Rodrigues EG. Manejo de resíduos gerados na assistência domiciliar pela estratégia saúde da família. Rev Bras Enferm. 2012;65(1):128-34.doi:10.1590/ S0034-71672012000100019.

15. Ferdowsi A, Ferdosi M, Mehrani Z, Narenjkar P. Certain hospital waste management practices in Isfahan, Iran. Int J Prev Med. 2012;3(Suppll):176-85.

16. Haylamicheal ID, Dalvie MA, Yirsaw BD, Zegeye $\mathrm{HA}$. Assessing the management of healthcare waste in Hawassa city, Ethiopia. Waste Manag Res. 2011;29(8): 854-62.

17.Vieira M, Padilha MI, Pinheiro RDC. Analysis of accidents with organic material in health workers. Rev. Latino-Am. Enfermagem. [periódico na Internet] 2011;19(2):[08 telas][acesso 13 set 212].Disponível em: http://www.scielo.br/pdf/rlae/v19n2/pt_15.pdf 18. Anagaw B, Shiferaw Y, Anagaw B, Belyhun Y, Erku W, Biadgelegn $F$, et al. Seroprevalence of hepatitis $B$ and $C$ viruses among medical waste handlers at Gondar town Health institutions, Northwest Ethiopia. BMC Research Notes 2012;5(55).

19. Souza MCMR, Freitas MIF. Representations of Primary Care Professionals about the Occupational Risk of HIV Infection. Rev. Latino-Am. Enfermagem. [periódico na Internet]. 2010; [acesso 13 set 2012]; 18(4). Disponível em: http://www.scielo.br/pdf/rlae/v18n4/pt_13.

20. Deuffic-Burban S, Delarocque-Astagneau E, Abiteboul D, Bouvet E, Yazdanpanah Y. Blood-borne viruses in health care workers: prevention and management. J Clin Virol. 2011;52(1):4-10.

21. Lee R. Occupational transmission of bloodborne diseases to healthcare workers in developing countries: meeting the challenges. J Hosp Infection. 2009;72(4):285-91.

22. Karout N, Altuwaijri S. Impact of health education on community knowledge, attitudes and behaviour towards solid waste management in Al Ghobeiry, Beirut. : East Mediterr Health J. 2012;18(7): 777-85.

23. Correa LB, Lunardi VL, Conto SM. The process of education in health: practical knowledge on solid wastes from healthcare services. Rev Bras Enferm. $2007 ; 60(1): 21-5$. 